\section{Vecherkovskaya A., Popereshnyak 5.}

\title{
MATHEMATICAL MODELING OF THE PROCESS OF FLUID FILTRATION THROUGH A MULTI-LAYER FILTERING ELEMENT
}

Розглядається математична модель прочесу фільтрачї рідини в пористому середовищі. Математична модель фільтрації рідини в пористому середовищі базується на рівнянні нерозривності і законі Дарсі для полого пористого циліндра. Запропонований метод організації розподілених розрахунків для кінщево-елементної моделі фільтрації може бути використаний при побудові гідродинамічної моделі процесу фільтращї, та ї програмній реалізащї, що і планується в майбутньому.

Ключові слова: математична модель процесу фільтрації рідини, пористе середовище, закон Дарсі, розподілені розрахунки.

\section{Introduction}

During motion of natural liquids (water, oil, gas) in natural soil, particles of fluid move through the layers of soil, that is, through thin channels formed between the particles of soil as a result of loose contact with each other. Such a motion of fluids through a multi-layered medium is called filtration. As a result of an extremely small cross section of openings and low motion speed, viscosity of the fluid, as well as other empirical coefficients, which take into account porosity of the sediment deposited on the walls of a porous space, should play a significant role in this motion. That is why it is a relevant task to build a mathematical model of the process of fluid filtration through a multi-layer filtering element in order to optimize production of filters for wells with a polypropylene coating in the industry. It would also consider water debit when installing into the aquifer layer while maintaining qualitative characteristics of the fluid.

\section{The object of research and its technological audit}

The object of study is the process of fluid filtration through a multi-layer filtering element.

Filtration is described by various types of experimental laws that establish the relationship between a velocity vector of fluid filtration and the field of pressure. There are several ways to describe mathematically the process of filter colmatation; we shall examine a single-component model of the suspension flow through a porous medium.

Based on the technological audit, within the framework of constructing the given model, we propose the following approximations:

1. A suspension of unspecified particles is filtered.

2. The parameters of clean filter are assigned to the entire porous system: its permeability and porosity.

3. The model takes into account the processes of mobilization and capturing of particles by the walls of channel of the filter's pores through filtration rate and a fluid pressure gradient.

4. Compression of the fluid and the solid body, as well as the diffusion of impurity, will be neglected.

In order to record a law of preservation of components of the filtered suspension, we shall consider a model of the medium that contains the following phases (Fig. 1) [1]:

1. A solid skeleton of the porous medium with porosity $m_{0}$.

2. Movable fluid with a volumetric fraction of porous space $S_{1}$

3. Solid particles in the flow of fluid with a volumetric fraction of porous space $S_{2}$.

4. Immovable fluid in the porous layer of settled particles with a volumetric fraction of porous space $S_{3}$.

5. Immovable particles that settled on the walls of the porous medium with a volumetric fraction of porous space $S_{4}$.

6. The speed of the particles and the speed of the carrier fluid are the same.

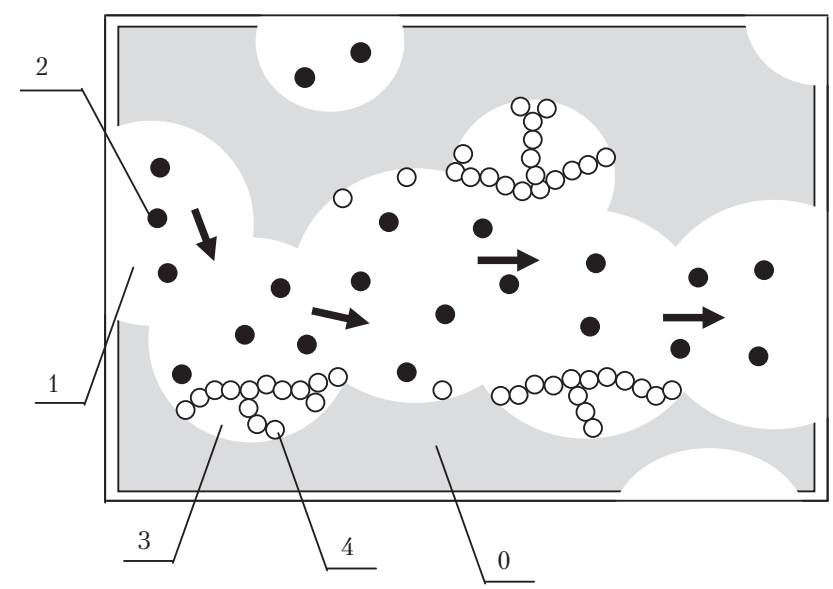

Fig. 1. Model of the suspension flow through a porous medium: 0 - a solid skeleton of the porous medium; 1 - movable fluid; 2 - solid particles in the fluid flow; 3 - fluid between the settled segments; 4 - parts that form a porous sediment 
By definition:

$$
S_{1}+S_{2}+S_{3}+S_{4}=1 \text {, }
$$

within the framework of the model, it is possible to write the following equations of the laws of component preservation:

$$
\begin{aligned}
& m_{0} \frac{\partial S_{1}}{\partial t}=\operatorname{div}((1-\varphi) \vec{U})-J_{1,3}, \\
& m_{0} \frac{\partial S_{2}}{\partial t}=-\operatorname{div}(\varphi \vec{U})-J_{2,4}+J_{4,2}, \\
& m_{0} \frac{\partial S_{3}}{\partial t}=J_{1,3}, m_{0} \frac{\partial S_{4}}{\partial t}=J_{2,4}-J_{4,2},
\end{aligned}
$$

where $\varphi=\frac{S_{2}}{S_{1}+S_{2}}$ is the volumetric fraction of solid phase in the flow; $J_{1,3}$ is the volumetric density of fluid flow that freely precipitates; $J_{2,4}$ is the volumetric density of colmatation flow; $J_{4,2}$ is the volumetric density of suffusion flow.

In order to connect free parameters in the equations of motion, it is necessary to add the coupling equation. As additional equations to describe physical processes of sediment deposition on the walls of capillaries of the porous medium and peculiarities of suspension's passing through a contaminated filter, it is possible to accept the following interrelations [1]:

$$
\begin{aligned}
& \varepsilon=\frac{S_{3}}{S_{3}+S_{4}}=\text { const, } \\
& \vec{U}=-\frac{k\left(S_{3}, S_{4}\right)}{\mu\left(S_{3}, S_{4}\right)} \vec{\nabla} p, \\
& J_{4,2}=\left(\beta_{s}+\beta_{d}|\vec{\nabla} p|\right) S_{4}, \\
& J_{2,4}=\left(a_{s}+a_{d}|\vec{U}|\right) \varphi, \\
& J_{1,3}=\left(J_{2,4}-J_{4,2}\right) \frac{S_{3}}{S_{4}} .
\end{aligned}
$$

In order to implement the model, it is required to assign 5 empirical coefficients $\left(\varepsilon, \beta_{s}, \beta_{d}, a_{s}, a_{d}\right)$ and 2 functions (density $k\left(S_{3}, S_{4}\right)$ and permeability $\left(S_{3}, S_{4}\right)$ ), which can be obtained from experimental data.

\section{The aim and objectives of research}

The aim of present study is to analyze a mathematical model of the process of fluid filtration in the porous medium.

To accomplish the set aim, the following tasks have to be solved:

1. To determine effect of empirical coefficients, which take into account porosity of the sediment deposited on the walls of the porous space, as well as linear functions that describe the adsorption and desorption of precipitation on the pore walls and functional dependence for permeability of the filter and viscosity of the suspension on the examined system.

2. To devise a calculation model, which makes it possible to utilize capacities of parallel computing systems with maximal efficiency.

\section{Research of existing solutions of the problem}

Filtering elements that are different in structural features typically contain three obligatory layers: filtering for the detention of mechanical impurities, coalescent or coagulating layer, and a drainage or water-repellent layer [2, 3]

In technical terms, the closest to the above filtering elements is a multilayer fibrous filtering element made of fibers of thermoplastic polymer, including polypropylene, which is described in [4].

The filtering element consists of layers that alternate between fine-fiber and thick-fiber layers. The thick-fiber layers are made of fibers with a diameter of 5-10 microns, the fine-fiber layers - of fibers with a diameter of 10-30 microns. Thickness of a thick-fiber layer can reach 12-254 microns, while thickness of a fine-fiber layer is 10-30 microns. The filtering medium is the fine-fiber layers, while the thick-fiber layers serve as a pad between the fine-fiber layers.

In [4], it is proposed to create a low-cost multi-layer filtering element of the filter-separator, which will provide a high degree of purification of gaseous and liquid media, such as natural gas and liquid fuel. It will also provide cleaning from both mechanical impurities and free moisture contained in the medium that is filtered in the form of aerosols [5].

There is a multi-layered filtering element for liquid and gaseous media, made from fibers of thermoplastic polymer, mostly polypropylene, which consists of alternating layers - fine-fiber and thick-fiber layers. This element is fabricated by the method of extrusion in the form of an empty cylinder with a thick-fiber outer layer; in this case, the thick-fiber layers are composed of fibers with a diameter of 100-150 microns, while the fine-fiber layers of fibers with a diameter of 1-5 microns [6].

The polypropylene fibers were employed to form, using the extrusion method, a filtering element in the form of a hollow cylinder, which is made up of seven layers [5]. Characteristics of the layers are given in Table 1 .

Table 1

Characteristics of layers' porosity

\begin{tabular}{|c|c|c|}
\hline Layer thickness in \% & Layer density, g/cm ${ }^{3}$ & Fiber diameter, $\mu \mathrm{m}$ \\
\hline 20 & 0.20 & $100-150$ \\
\hline 15 & 0.40 & $1-5$ \\
\hline 7.5 & 0.20 & $100-150$ \\
\hline 15 & 0.30 & $1-5$ \\
\hline 7.5 & 0.20 & $100-150$ \\
\hline 15 & 0.25 & $1-5$ \\
\hline 20 & 0.20 & $100-150$ \\
\hline
\end{tabular}

One of the materials is characterized by a nonlinear dependence of filtration coefficients on the pore pressure, which renders the model essentially nonlinear.

For the purpose of mathematical modeling of the hydrodynamic influence, a porous cylinder can be represented as a two-phase saturated porous medium, consisting of 
a solid phase of the skeleton and a liquid phase of the fluid that is filtered in the pores.

If a deformation of the porous body is taken into account, the porous medium can be represented only by the equation of filtration.

It is known from papers [7, 8] that the motion of viscous fluid is described by the Navier-Stokes equation, which is why in order to describe the motion of viscous fluid in a porous medium, it will suffice to integrate this equation in the region of motion. However, as a result of sharp non-uniformity of the porous space and a lack of information about specific structure of the pore channels, this task is practically impossible. Solving this problem is possible for a limited set of perfect periodic structures that are the approximation of real structure of a certain type of porous layer, and can only serve for qualitative description [9] and has no significance for practical calculations.

\section{Methods of research}

In order to write the equation for pulses, the following dependence of filtration rate is assumed in a general case:

$$
\vec{u}=f(\nabla p, k, \mu, \phi)
$$

where $p$ is the hydrodynamic pressure; $k$ is the permeability of a porous medium; $\mu$ is the dynamic viscosity.

A particular type of function depends on the problem under consideration. The simplest and widely used model is a model of the Darcy linear law [10]. This model is well studied theoretically and practically, and implies a linear relationship between a pressure gradient and the filtration rate:

$$
\vec{v} \phi=\vec{u}=-\frac{k}{\mu} \nabla p,
$$

where $\vec{v}$ is the mean real rate of fluid.

It is also necessary to define other empirical dependences of filtration rate on pressure gradient. In a general case, a non-linear filtration law can be written in the form [11]:

$$
\nabla p=-f(|\vec{u}|) \frac{\vec{u}}{|\vec{u}|}
$$

or

$$
\vec{u}=-\frac{\nabla p}{|\nabla p|} f^{-1}(|\nabla p|)
$$

where $f^{-1}$ is the function inverse to $f$.

The filtration law is sometimes assigned in the indicator form [11]:

$$
\vec{u}=-\frac{\nabla p}{|\nabla p|} C|\nabla p|^{n}
$$

where $C$ is a constant, which is defined experimentally; $n$ is the index of filtration mode [11].

Also common is the two-term law of filtration:

$$
-\nabla p=\frac{\mu}{k} \vec{u}+C \rho \vec{u}|\vec{u}|
$$

where $C$ is an experimental constant.
In the case of filtration with an initial displacement gradient, the Darcy law takes the following form:

$$
\vec{u}=\left\{\begin{array}{l}
\frac{k}{\mu}\left(\nabla p-G \frac{\nabla p}{|\nabla p|}\right),|\nabla p|>G \\
0,|\nabla p|<G
\end{array}\right.
$$

where $G$ is the magnitude of the displacement boundary gradient.

In some cases, correct description of filtration is possible only by employing a full-scale 3D hydrodynamic model. Under such approach, integration of the system of differential equations will be performed by numerical methods. One of the most common current numerical methods is the method of finite differences. The main advantage of this method is its universality. However, when solving inverse problems, there occur computational difficulties in its application. Therefore, in order to carry out evaluation calculations, the analytical and numerical-analytical models are required, deprived of this shortcoming. It is also necessary to note that for a good approximation of the solution, it is necessary to add a step, which also affects the efficiency of calculation. In the given case, it also helps to employ analytical models for the asymptotic description of solution near a feature, while it is possible to use numerical methods far from the feature [12].

Effective technique for calculating complex models is the use of parallel programming methods, which make it possible to split computation into streams that are performed on the basis of supercomputers, clusters and other high-performance computing systems.

Since the most time-consuming is the stage of solving a linear system of equations, then for effective implementation of distributed computing one can either develop parallelization options for the known algorithms when solving SLAE, or construct new algorithms that employ parallelism.

Distributed direct solvers can be applied for parallel architecture with a small number of processors, because they require frequent communication between the processors. More effective for the parallelization are iterative procedures because of their low storage requirements. However, recently, direct solvers have been used in combination with an iterative solver for the development of reliable prerequisites.

Effective distributed iterative solvers are based on the predetermined conjugate gradient method. Examples are the distributed predetermined method of conjugate gradients (Distributed PCG, DPCG), and the Distributed Jacobi Conjugate Gradient (Distributed JCG, DJCG).

\section{Research results}

Solving the finite-element problems using parallel computers with distributed memory implies the following [13]. First, one prepares input data for separate processors, then a parallel generation of the finite element grid is performed, followed by a parallel assembling of matrices and vectors of irregularities, next is the parallel solving of the systems of equations, which results in parallel processing of the results of solution.

Solving a finite-element system is possible in the following way:

1. Imagine the assigned grid using a matrix whose elements match the nodes of the grid. 
2. Next, we shall split this matrix into bands by the number of computed nodes, passing over to them the corresponding regions of the matrix (Fig. 2).

3. Initial value of the function of pressure in each cell is assigned by the initial conditions of the problem.

4. Computing nodes forward to their neighbors respective «conjugate regions» of their bands.

5. For each band, one calculates the values for all of its elements in time $t_{k}$ with the use of their values at elements from the obtained conjugate regions of adjacent bands (Fig. 3).

6. Computations (points 4, 5) continue until the system reaches equilibrium. time $t_{k-1}$, boundary conditions, as well as the values for

ring instruments and qualified specialists, which directly increases the cost of production of reference filtering elements for different types of fluid.

Opportunities. The model proposed will make it possible to automate the production of filtering elements with the purpose of optimization of the number of layers by their structure and volume in order to achieve certain defined filter properties, such as a capacity to withstand contamination, changes in pressure, filtration patterns, performance efficiency, taking into account the features of suspension. A promising direction for further research is the combination of a mathematical model of fluid filtration through a multi-layer filtering element with a method for the optimization of the process of perforating the casing pipes by determining the combination of cycle parameters with a reference to coordinated machine tools. This will enable optimal location of openings and determining their dimensions taking into account the formation of filtering layers of predetermined density and thickness on the perforated pipe, as well as a sufficient good-quality fluid debit.

Fig. 2. Matrix representation of the grid

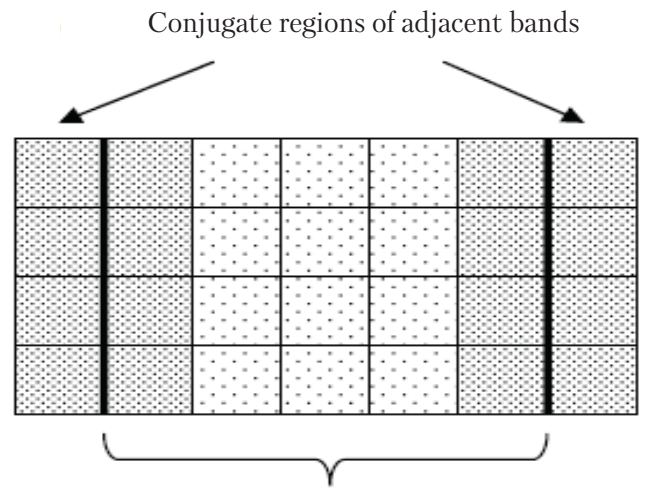

Band

Fig. 3. Elements that are used by the calculating node

\section{SWOT analysis of the research results}

Strengths. The proposed model of computation makes it possible to utilize capacities of parallel computing systems with maximal efficiency, minimizing data transfer between their nodes by forwarding only the adjacent regions, as well as the idle time of separate nodes due to the symmetric allocation of load [14, 15].

Note 1. In the case of a uniform grid, the values of an element can be calculated as the arithmetic mean of neighboring elements.

Note 2. In the case of a quasi-uniform grid, element's values can be calculated as the arithmetic mean of adjacent elements considering a correction for weight coefficients introduced in line with a special procedure.

Weaknesses. The given mathematical model of the process of fluid filtration through a multi-layer filtering element requires the presence of high-precision measu-
Threats. The need for such a model is predetermined by the fact that industrial production traditionally employs techniques and programs that are based on the practically created approach, which typically contain seven filtering layers with the averaged value of the filter thickness [5]. At present, the automated production of multilayer filtering elements is not used at Ukrainian enterprises. The implementation of the given model in industry requires additional funding for re-equipment and for expansion of material base of production, as well as the necessary laboratory tests of experimental samples of the filtering elements with a given density and thickness of the layer.

\section{Conclusions}

1. We established that empirical coefficients $\left(\varepsilon, \beta_{s}, \beta_{d}\right.$, $\left.a_{s}, a_{d}\right)$, functions of density $k\left(S_{3}, S_{4}\right)$ and permeability $\left.\mu\left(S_{3}, S_{4}\right)\right)$, which take into account porosity of the sediment deposited on the walls of a porous space, as well as the linear functions that describe the adsorption and desorption of precipitation on the pore walls, and functional dependences of the filter permeability and the suspension viscosity, exert a significant impact on the examined system and can be obtained from experimental-research data.

2. The model of computation is proposed, which makes it possible to utilize capacities of parallel computing systems with maximal efficiency, minimizing data transfer between their nodes by forwarding only the conjugate regions, as well as the idle time of separate nodes due to the symmetric allocation of load.

\section{References}

1. Parmakli, I. I. Rasprostranenie volny zagriazneniia pri fil'tratsii suspenzii v poristoi srede [Text] / I. I. Parmakli, S. A. Poslavskii // Materialy mezhdunarodnoi konferentsii «Sovremennye problemy matematiki i eio prilozheniia $\mathrm{v}$ estestvennyh naukah i informatsionnyh tehnologiiah». - Kharkiv, 2012. - P. 84. 
2. Tieffilterpatrone und methode und vorrichtung zu deren herstellung [Electronic resource]: Patent DE 69331102 T2 / Szczepanski C., Aune M., Schneider J.; assignee: Osmonics Inc. - Appl. No. DE1993631102; Filed August 19, 1993; Publ. August 22, 2002. - Available at: \www/URL: http://www.google.com.pg/ patents/DE69331102T2

3. Koaleszenzelement [Electronic resource]: Patent DE 69723714 D1 / Whitney A., Williamson M., Clendenning A., Hibbard R., Griffin M.; assignee: Pall Corp. - Appl. No. DE1997623714; Filed September 30, 1997; Publ. August 28, 2003. - Available at: \www/URL: http://www.google.com.pg/patents/DE69331102T2

4. Construction of filter (versions) and method of filtration [Electronic resource]: Patent RU2182509C2 / Calbau B., Dadri D. J.; assignee: Donaldson Company, Inc. - Appl. No. RU2000109355A; Filed September 9, 1997; Publ. May 20, 2002. - Available at: \www/URL: https://patents.google.com/patent/RU2182509C2/en

5. Fil'troval'nyi element dlia zhidkih i gazovyh sred [Text]: Patent RU 2326716; MPK VO1D 39/16 (2006.01) / Troian D. A.; assignee: Scientific and Productive Firm «Rubicon», Private Enterprise «Unifilter». - Appl. No. 2006124622/15; Filed January 20, 2008; Publ. June 20, 2008, Bull. No. 17. - 5 p.

6. Vecherkovskaya, A. Comparative analysis of mathematical models forming filter elements [Text] / A. Vecherkovskaya, S. Popereshnyak // 2017 XIIIth International Conference on Perspective Technologies and Methods in MEMS Design (MEMSTECH).IEEE, 2017. doi:10.1109/memstech.2017.7937545

7. Basniev, K. S. Neftegazovaia gidromehanika [Text]: Handbook / K. S. Basniev, N. M. Dmitriev, G. D. Rozenberg. - MoscowIzhevsk: Institute for Computer Research, 2005. - 544 p.

8. Selivanov, V. V. Mehanika razrusheniia deformiruemogo tela [Text]: Handbook / V. V. Selivanov // Prikladnaia mehanika sploshnyh sred. - Moscow: MSTU n. a. N. E. Bauman, 1999. Vol. 2. $-420 \mathrm{p}$.

9. Hasanov, M. M. Opredelenie optimal'nogo perioda otrabotki nagnetatel'noi skvazhiny na neft' [Text] / M. M. Hasanov, V. A. Krasnov, V. A. Korotovskih // Nauchno-tehnicheskii Vestnik OAO »NK »Ros-neft». - 2007. - No. 5. - P. 19-22.

10. Darcy, H. Les fontaines publiques de la ville de Dijon [Text] / H. Darcy. - Paris, 1856. - 647 p.

11. Charnyi, I. A. Podzemnaia gidrogazodinamika [Text] / I. A. Charnyi. - Moscow-Izhevsk: SIC »Regular and chaotic dynamics», Institute for Computer Research, 2006. - 436 p.
12. Andrianov, I. V. Asimptoticheskaia matematika i sinergetika: put' $\mathrm{k}$ tselostnoi prostote [Text] / I. V. Andrianov, R. G. Barantsev, L. I. Manevich. - Moscow: Editorial URSS, 2004. - 304 p.

13. Wriggers, P. Nonlinear Finite Element Methods [Text] / P. Wriggers. - Springer Berlin Heidelberg, 2008. - 560 p. doi:10.1007/978-3-540-71001-1

14. Sementsov, H. N. Development of informative support for automatic antisurge protection system and regulation of gas pumping plant [Text] / H. N. Sementsov, L. I. Davydenko // EasternEuropean Journal of Enterprise Technologies. - 2014. - Vol. 4, No. 11 (70). - P. 20-24. doi:10.15587/1729-4061.2014.26311

15. Vambol, S. Assessment of improvement of ecological safety of power plants by arranging the system of pollutant neutralization [Text] / S. Vambol, V. Vambol, O. Kondratenko, Y. Suchikova, O. Hurenko // Eastern-European Journal of Enterprise Technologies. - 2017. - Vol. 3, No. 10 (87). P. 63-73. doi:10.15587/1729-4061.2017.102314

\section{МАТЕМАТИЧЕСКОЕ МОДЕЛИРОВАНИЕ ЛРОЦЕССА ФИЛЬТРАЦИИ} ЖИДКОСТИ ЧЕРЕЗ МНОГОШАРОВЫЙ ФИЛЬТРУЮЩИЙ ЭЛЕМЕНТ

Рассматривается математическая модель процесса фильтрации жидкости в пористой среде. Математическая модель фильтрации жидкости в пористой среде базируется на уравнении неразрывности и законе Дарси для полого пористого цилиндра. Предложенный метод организации распределенных расчетов для конечно-элементной модели фильтрации может быть использован при построении гидродинамической модели процесса фильтрации, и ее программной реализации, что и планируется в будущем.

Ключевые слова: математическая модель процесса фильтрации, пористая среда, закон Дарси, распределеные расчеты.

Vecherkozskaya Anastasia, Senior Lecturer, Department of Software Engineering, National Aviation University, Kyiv, Ukraine, e-mail: post@nau.edu.ua, ORCID: http://orcid.org/0000-0003-2054-2715

Popereshnyak Svitlana, PhD, Associate Professor, Department of Software Systems and Technologies, Taras Shevchenko National University of Kyiv, Ukraine, e-mail: fit@univ.net.ua, ORCID: http:// orcid.org/0000-0002-0531-9809 